\title{
STATE AND RELIGION IN ACEH: The Competences of Religious Education Teachers (Referring to ACT 14, 2005)
}

\author{
Mujiburrahman \\ Ar-Raniry State Islamic University, Banda Aceh \\ Email: mujiburrahman@ar-raniry.ac.id
}

\begin{abstract}
Studies on religious education teacher's competences in Aceh could not be separated from studies on state's intervention toward education. State hegemony occurs in the form of regulation formalization which regulates efforts for improving qualification and competence of teachers. The research showed that the presence of Act No. 14, 2005 and the Government Regulation No. 74, 2008 had been used as legal reference to encourage the improvement of Aceh religious education teachers' qualification and competence. This is a qualitative study in which triangulation in data collection was used. The data was then collected through documentations, observations, and deep interviews. This work emphasizes that improving teachers' competences in Islamic education system in Aceh was in accordance to and did not contradict with national education system and moreover strengthen the content of Act No. 14, 1005 and Government Regulation No. 74, 2008. Qualification and competence of religious education teachers in Aceh underwent improvement better than previous term. However, teachers experienced that socialization process and implementation of regulation has yet to receive upmost attention. The study also suggests that religious education teachers' qualifications and competences will significantly contribute to the development of religious education quality, thus Islamic education transforms intently in national and state relations order.
\end{abstract}

Keywords: Policies, Teacher, Competence, Religious, Education, Religious, State, Relation

\section{INTRODUCTION}

The Government Regulation on teachers has been implemented in the past ten years. However, the quality and professionality of Indonesian teachers seems to be still problematic, particularly in Aceh. The condition of Aceh education has become into attention of many experts (i.e. Goto et al., 2012; Oktari, Shiwaku, Munadi, Syamsidik, \& Shaw, 2015; Shah \& Lopes Cardozo, 2014). Rosemary and Mahdi (2013) show that education in Aceh which is based on Islamic value is relatively different from national education, since the latter is 
based on three pillars, accessibility, quality, competitiveness and governance, accountability and public image (Rosemary, $\mathrm{Si}, \&$ Mahdi, 2013). The presence of Act No 14, 2005 to improve religious education teacher's competences and quality in the Aceh province which is protected by the implementation of Sharia law does not reach significant improvement (Zulfikar Ali Buto, 2016).

This is evident from the result of teacher competence test (UKG) in Aceh Province of 37.62. It was far from national average score. Meanwhile, UKG national average score was 43.84 (Iskandar, 2012). In 2015, teacher competence test result in Aceh ranked 32 out of 34 provinces in Indonesia, with average score of 45.27 (Kemendikbud, 2016). On the other hand, this result suggests that teacher's competences in Aceh is still weak. These weaknesses cover several respects, such as: 1) lack of teacher's capability in developing teaching materials, 2) lack of teacher's knowledge about their roles and responsibilities in schools, and 3) discrepancy between educational background and subject being taught (Feralys Novauli. M., 2015: 46). One of the reasons for the difficulties to improve teacher's quality is as the result of the failure in the implementation of the Acts, no. 14, 2005. Phenomenon of the difficulty of implementing the policy is cleared and supported by several research on implementation of undergoing policy (Nakamura,1987; Lypski, 1980; dan Hjern, 1981).

Previous studies suggest that research on improving teacher's quality mainly reviews three aspects. Firstly, research on policy and developing education program. Talking about educational policy, Mintrop (1999:274) finds inconsistency of regulation which is overlap in three factors including institutional reference frame, self-reference frame (teacher) and learner reference frame as perspective to see educational policies. Secondly, research on education and developing teacher's profession. According to Avalos ( $\mathrm{Ma}$, et al, 2018: 292), developing teacher's profession is related to teacher's learning, learning about teaching strategies, and transforming knowledge for the sake of student's development. Thirdly, research on improving teacher's quality and competence, Pantic, Wubbels, and Mainhard (2011: 165) state that teacher's competence is classified into four respects including (a) self-evaluation and profession development, (b) knowledge on subject, pedagogy and curriculum, (c) understanding on educational system and contribution in development, and (d) values as well as childcare.

Of these trend, there is a negligent or lack in term of correlation between text and context of Act No 14, 2005 and needs and developing education in Aceh nowadays (especially in the context of Aceh, whose majority population is Muslim). This suggests the need to consider socio-religious and socio-cultural 
values among Aceh people themselves upon developing educational quality (Abubakar, 2013). At the same time, the substantive message on the Act is not well delivered to teachers. Furthermore the implementation of the Act applies into Lembaga Pendidikan dan Tenaga Kependidikan (LPTK) as the institution producing prospective religious education teachers in Aceh. The shortcoming explanation becomes the main focus of reviews in this article which filling the gap the previous studies by answering three questions; 1) how is the formulation of Act No 14, 2005 related to development of objective trends in education in Aceh nowadays?; 2) how can the implementation and message of Act No 14, 2005 be accepted by teachers as users for improving competence in Islamic education system in Aceh?; how is the ability of LPTK as the institution which produces the next religious education teachers in Aceh?; and 3) how is the implementation of Act No. 14 year 2005 which encourages the occurrence of the transformation of religious education in nation development be realized?

This work is based on three assumptions as the cores of the discussion and focus of the review. Firstly, the formulation of Act No 14, 2015 is not based on objective trends taking place in educational field nowadays (the Act is not relevant and not conceptual) and is not based on social reality of the Acehnese who are known to be religious. Therefore the effort to improve teacher's quality and the quality of Islamic education is difficult to achieve. Secondly, the implementation and the message of Act No. 14, 2005 that has cultural and structural constraints does not fully reach teachers, which is the main targeted group of the Act, and not reach LPTK as well especially as the institution which has the authority to produce prospective (religious education teacher). Therefore mission on improving competency is hard to achieve. Thirdly, the transformation of religious education in the process of nation building will suffer from significant obstacles if the improvement of religious education teacher's competency cannot be realized well. These three assumptions are the basis of this article.

This review employs qualitative method (Atkinson 2017; Stenius et al. 2017) I have come to understand that a solid grounding in the philosophical foundations and ethical considerations of one's fi eld of study are imperative for the success of any research endeavor. Whenever scholars have a strong grasp on their philosophical foundations, they are well prepared to comprehend the methods that they will utilize to study social activism. Note, CHAPTER TWO Research Methodologies This chapter explores: (1 focusing on three cities in Aceh including Banda Aceh, Lhokseumawe and Langsa. The three cities were chosen as the focus of this study because of four reasons. First, they have 
similar geographical, social and cultural values, as well as social and religious condition. Second, generally, the rate of institutional progress and quality in the three cities is relatively alike. Third, religious education teachers in the three cities are well-qualified. This study uses triangulation method which combines three different methods of data collection; observation, in-depth interview, and document analysis. Observation was conducted to observe and see teacher's activities as well as management and activities of educational institutions (LPTK). Document analysis was used to obtain the data related to the theories on research substance, and review of regulation substance which became focus of this study. In depth interview was conducted to obtain data from main sources consisting of religious education teachers, and the LPTK managers.

\section{RELATIONS BETWEEN STATE AND RELIGIOUS EDUCATION}

Indonesian religious education policy and system are designed to strengthen the relationship between state and religion. In Islam, there is no a conflict between political leaders and religious leaders. Islam does not have priesthood and also does not have a church-like institution. The Islamic teaching covers a wide range of areas, including politics, law, economy, social, and culture (Deliar Noer, 2003). Meanwhile, Muhammad Abed al-Jabiri (2001) explains that throughout the history, there is no conflict between the state and religion. The dichotomy only took place in the west (especially in the Roman empire) when church was ruled by a group of priests.. Therefore, relationship between religion and state becomes an interesting discourse since the first era of religion until now. Social-political stability also has a role in the relationship of religion and state which goes up and down, especially in affecting policy and politics of education.

Education and politics are two essential elements in social and political system in all countries (Baker, 2014). The involvement of government is basically to play and realize roles in public policy-related development which is implemented by a government (Edited by Karen Mundy, Andy Green, Bob Lingard, 2017). The State often intervenes national education system through regulation issued (Yusuf and Sterkens, 2015). Developing teachers' competency and quality through implementing Act Number 14, 2005 cannot be separated from the policy and politics of education run by the government. Teachers' competency is defined by Tichá and Hospesova (2012: 134) as a series of qualifications, abilities and characters which are needed to realize professional success and the competence and an ability to act as needed to respond to the situations during teaching, as well as to improve the quality of 
learners.

The policy about teacher's competency is essentially made to fulfill needs of education in order to achieve its goals. However, as explained by Cohen, Moffitt and Goldin (2007: 515), policy and its implementation raise a dilemma between the policy and the educational practitioner's ability to use the policy to solve educational problems. On the contrary, the realization of policy itself depends on the abilities of those who support the implementation and goals. In the government's regulation, teacher's competence becomes one of the aspects in educational policy. Educational policy-related problem was shown to describe the existence of inequal value, as explained in journal of Harvard Law Review which shows the term inconsistence of regulation as inequality of formulating policy among educational policies in the constitution (The Harvard Law Review Association, 2015: 941). The problem is emphasized by Mintrop (1999: 274) that inconsistence is as overlap regulations in three factor models, self-reference frame, institutional-reference frame and learnersreference frame as perspective to see educational policy.

A discussion about teacher's competency cannot be separated from reviews on professional education, because both are related. Avalos (Ma, et al, 2018:292, Klingstedt, et al (1981: 15-22) explains that developing profession for teacher is related to teachers' learning, learning the way to teach, and transform knowledge for students' development. Furthermore, Rebell and Molly (2014: 691) state that standardized and effective instructor is the key element to improve students' achievement. Therefore, all professional educators must focus on the aim to realize improving students' achievement. Moreover, Rebell and Molly (2014: 694) explain that teacher profession education forms in the process of adjusting curriculum between standard of teacher training and standard of students learning through teacher's certification test, a test of various aspects of qualification as an effort to validate knowledge and skills needed in teacher profession. In teacher education context, education for teacher program is explained by Ludington (1940: 263) by considering social condition in which teacher profession becomes an experiment center to answer social problem. Professional education is a place to transform problem faced in education (Barney, 2004, Cooney (1994: 631).

Basic competence which must be understood by the teachers is pedagogical competence. Moreover, teacher's competence of pedagogy is the basic need for a teacher. Liakopoulou (2011: 475-476) explains that criteria in valuing the pedagogical competence is likely based on the result standard approach or learner's performance, teacher's performance standard approach, teacher's responsibilities evaluation, and competence standard criteria. In 
Balkan countries, According to Pantic, Wubbels, and Mainhard (2011: 165), teacher's competence is classified into four aspects; (1) self evaluation and developing profession; (2) subject's knowledge, pedagogy and curriculum; (3) understanding educational system and its contribution on development; and (4) value as well as parenting. Besides pedagogy competence, personality competence is also a measurement to know the readiness of teacher. Teacher's personality is a key factor for teacher's teaching effectiveness (Symonds, 1947: 653-654, Barr, 1960: 400-405). Besides personality, a teacher needs social competence which is useful to understand social dynamic in the class (Gehlbach, 2010: 351). In addition, a teacher should understand roles of profession and should have professional competence. Dreher and Kutze (2015: 110) emphasize the importance of understanding an interaction between teachers and students in which professional knowledge of teacher connects to various representation of roles in learning.

\section{THE FORMULATION ACT NO 14 OF YEAR 2005 WITH THE DEVELOPMENT OF RELIGIOUS EDUCATION SYSTEM IN ACEH}

The Structure and the formulation of Act No. 14, 2005 consist of 8 chapters and 84 articles. Based on substantive analysis of Act UU No 14, 2005 in chapters and articles which are related to teachers, it can be understood that the presence of the Act is to: 1) Legally and formally Approving functions, roles and strategic positions of teacher in national development in Educational field; 2) Enhancing dignity of teacher as professional educator which is proven with educator certificate; 3) Managing duties and rights of teachers in conducting their professional responsibilities 4) Empowering and improve quality of teachers accordingly, directly and sustainably; and 5) Providing a safe and healthy working for teachers in performing their duties and sanctions if they neglect their responsibilities as regulated in the Act.

Teacher's competency in Act No. 14, 2005 is contained in article 10, at verse 1 which states that "teacher's competency as stated in verse 8 are pedagogy competency, personality competency, social competency, and professional competency, which are obtained in education for profession. Verse 2 states that: "further requirements about teacher's competency as meant at verse (1) are regulated in government's regulation" (Act. No 14, 2005). Material about teacher's competency which is contained in Act No. 14, 2005 is still general that is a basic concept of substance of competence which must be possessed by a teacher. The basic concept which is general and conceptual must be explained in detail and specifically in term of operation which is implemented. Therefore, the explanation about the Act is revealed in the Government's Regulation No. 
74, 2008 about Teacher. Discussion about teacher competency is explained comprehensively and in detail in article 3, verse 1-7.

(1) Competency as described in verse 2 is a group of knowledge, skill, and behavior which must be possessed, perceived, mastered, and actualized by teachers when conducting their professional duties.

(2) Teacher's competency as described in verse (1) consists of pedagogical competence, personal competence, social competence, and professional competence which are obtained through education for profession.

(3) Teacher's competence as described in verse (2) is holistic.

(4) Pedagogical competence as described in verse (2) is teacher's ability in managing learning of students which at least consists of: a) understanding about insights and the basis of education; b) understanding learners; c) developing curriculum and syllabus; d) designing learning; e) performing educated and dialogic learning; f) utilizing learning technology; g) evaluating learning results; and $\mathrm{h}$ ). developing learners to actualize their various potencies. .

(5) Personal competence as described in verse (2) consist of at least personality that is: a) faithful and fearful of God, b) good attitude, c) wise, d) democratic e) steady, f) commanding, g) stable, h) mature, i) honest, j) sportsmanship, k) becoming an example for learners and society, l) objectively evaluating their performance, and $\mathrm{m}$ ) self-developing independently and sustainably.

(6) Social competence as described in verse is (2) teachers' ability as part of society which consists at least: a) being able to communicate spoken, written/ or sign language decently, b) being able to utilize communication and information technology functionally, c) being able to associate effectively with learners, other educators, educational personnel, leaders in educational institution, and parents or students' representative, d) being able to associate decently with surrounding society by honoring norms and values; and e) implementing real brotherhood principal and spirit of togetherness.

(7) Professional competence as described in verse (2) is teachers' competency in mastering their subject, technology, and/or art and culture at least mastering as follows: a) mastering material about their subject comprehensively and deeply based on standard of educational server program, subject, and/or a group of subjects that will be taught; and b) mastering concepts and methods of relevant subject, technology and art which conceptually apply or are coherent with educational server program, subject, and/or a group of subjects that are taught (PP. No. 74, 2008). 
Competency in Act No. 14, 2005 and the Government's Regulation No. 74, 2008 can be defined as knowledge, skills and attitude which are shown in form of willing, smart, fully responsible behavior belonging to a teacher in conducting his/her profession. A teacher is required to have competencies in performing his/her profession, ability to well interact socially with learners, other teachers, principals, and even with society. This thought is emphasized by Usman (2007: 262) that every competency basically contains 6 elements; (1) performance: performing based on their field; (2) subject component; mastering material/substance of knowledge and technical skill based on their field; (3) professional; substance of knowledge and technical skill based on their professional field; (4) process: an intellectual ability such as logical thinking, problem solving, creative, decision making; (5) adjustment: selfadjustment; (6) attitude: attitude, personality value.

In the context of the Aceh educational system, understanding the Act No. 14, 2005 and the Government's Regulation No. 74, 2008 above becomes juridical basis which can work and strengthen together with formulation of Act No. 11, 2006 about Aceh Government and Qanun No. 11, 2014 about performing education in Aceh. Normatively, these four juridical basis have been composed based on the value and philosophy that encourage improvements and changes in society. Normative dimension perceives that all policies, which are goals of society, basically are very normative. In relation with that, substance of value and goal which will be gained by implementing Act UU No. 14, 2005, The Aceh Government Act No 11,2006, Government Regulation. No. 74, 2008, and Qanun of Aceh No. 11 year 2014 in aspect of teacher is improvement of qualification and competency of teacher in order that improvement of educational quality and service will rise for Aceh people entirely.

Improvement of quality and service of education for the Acehnese is conceptually and technically explained in the Islamic concept of Aceh education. Concept of Islamic education is explained in Qanun of Aceh No. 11,2014 , in chapter I article 1 verse (21) which defines Islamic education as "an education which is based on values of Islam teachings" (Qanun of Aceh, 2014). Islamic values become the basis and soul of education. Islamic education's principle is universal and binding as found in article two that "Islamic values, nationalism, Acehism, truth, humanity, justice, beneficial, affordability, professionality, example, diversity, and non discrimination" (Qanun of Aceh, 2014). The explanation in article 1 and 2 provides an understanding that there is specificity of Aceh educational system, which is based on Sharia.

This specialty has direct influences on efforts made in improving teachers' competence in Aceh and other regions in Indonesia. As the Aceh educational 
system has been based on the sharia law, it ways of improving teachers' competence are to same extent distinct to that of other regions across Indonesia. This is reflected from the Qanun of Aceh No 11, 2014 regarding the requirement to be a teacher in the Aceh province. Article 48, for example, states that "to be a teacher, one must fulfill requirements as follows: a. having academic qualification according to level and kind of education based on regulation and Act; b. having professional competency, pedagogical competence, personal competence and social competence which are proven by the result of competency test; c. having good attitude and being able to recite Qur'an for Muslim; d. Mentally and physically healthy; and e. free from narcotics" (Qanun of Aceh, 2014).

The Qanun of Aceh in article 38 states that to be eligible as prospective teachers, ones have to be competent in pedagogical competence, personal competence, social competence, and professional competence). These important requirements are very much relevant to the Act No. 14, 2005 and the Government's Regulation No. 74, 2008. However, there is different and unique aspect which is added as a requirement to be a qualified teacher in Aceh, i.e. free from narcotics and being able to recite the Quran (only for Muslim teachers). This policy is in accordance with the requirement of Islamic education system implemented in Aceh. Because Islamic education concept is based on Qur'an and hadith of Prophet Muhammad PBUH, reciting and understanding the content of Koran are required for teachers working in Aceh. The ability to read the Quran is an integral part of developing pedagogical competence which means that mastering content of Qur'an and Hadith as an enrichment of learning material. Logical consequence provides a logic conclusion that developing teacher's competency in Islamic education system in Aceh is in accordance to and not contradicts to national education system and strengthens contents of the Act No. 14, 2005 and the Government's Regulation No. 74, 2008.

\section{THE IMPLEMENTATION OF ACT NO 14 OF YEAR 2005 TOWARD IMPROVING RELIGIOUS EDUCATION COMPETENCY AND LPTK}

The comprehensive implementation of the Act No. 14 year 2005 nationally around Indonesia, including Aceh, contains of three massive programs to improve teacher's quality. First is a program to improve qualification of education for teachers (Bachelor of religious education teacher qualification). This program is advanced education program at undergraduate level (S1) for teachers who do not have Diploma of Bachelor. Second, certification program for teachers (PSG) is held to educate and select some teachers. Those who have competency will be eligible for educator certificate as a requirement to 
obtain teacher certification. Third, education for teacher profession program (PPG) is held to professionally train teachers who have competency and skills related to teacher training. Besides PPG, there are other forms of education and training held in order to improve the quality of religious education teachers in Aceh including training for developing learning theory, learning methodology, media, and learning source, management and program, as well as developing learning evaluation for religious education teachers.

These three programs have been held since 2007 until now. According to data from faculty of Education and Teacher Training, UIN Ar-Raniry as LPTK which is given a mandate by the government to hold the program, it can be seen that there are some programs being done. DUALMODE SYSTEM program, from 2010 to 2014, has successfully trained and graduated 1.764 teachers of Islamic elementary school and Bachelor program of religious education teacher. In 2010, it has graduated 378 religious education teachers, Program of education for teacher profession (PPG), from 2013 to 2014: 156 graduates, Program of teacher certification (PSG), which has been being held since 2007 until 2014, and has successfully trained and graduated 1.584 teachers (a report of LPTK UIN Ar-Raniry, 2017).

Through various programs above, religious education teachers has generally perceived a benefit which directly affect on the improvement of self-quality and self-competency. Below is a statement of one of the religious education teachers in Banda Aceh.

After the implementation of Act on teacher, I get an opportunity to take part in teacher certification program in 2010 in Faculty of Education and Teacher Training IAIN Ar-Raniry Banda Aceh. During my involvement in the training program, I obtained so much knowledge, especially about the Act on teacher which is related to competency that is required for teacher in teaching. In addition, I perceived that I have knowledge and experience of active, creative and fun teaching by implementing PAKEM approach that is provided by the teacher. Moreover, I gain precious experience and knowledge during teaching practice through peer teaching pattern which is part of learning together process. In conclusion, after I finished my training, I obtained much knowledge about teaching theory, I can feel that there is a change and improvement of my quality and capacity rather than before (Interview with AR, October, 2017).

Improvement of capacity and competency of teachers as experienced by a teacher, AR, after following certification for teacher program, will give positive impact toward performance and improvement of education quality. 
In this term, Destiana (2012) explains that there is a positive relationship between pedagogical competence and elementary teacher's performance. A bad teacher's performance is likely caused by lacks of knowledge, skills, motivation, and belief of the teacher himself. Teachers who perform well have good pedagogical competences. Consequently, an effort to improve teacher's performance can be done by giving more focus to their pedagogical competence. However, teachers who have low competence will give negative impacts to their profession and performance.

The research found that some teachers in Lhokseumawe have lack of competence in using instructional media effectively. This suggests that instructional media has yet to be developed effectively by the teachers they do not fully utilize media that they create. The use of media is still in consumptive matters as general media today. Writing media is often used to teach Qur'an and Hadith subject, akidah akhlak subject, and Islamic culture and history subject. Sometimes electronic media or kinds of it are used in teaching the Qur'an, especially teaching standard competency of Qur'anic recitation.

The existence of competency and quality of teachers which is mostly low is often pointed as LPTK's mistake, as the institution that produces them. It is recorded in explanation by Director General of Islamic Education, Prof. Dr. Kamarudin Amin, MA.

“There is a perception among society, if teacher's quality goes down. It is the mistake of LPTK. It is reasonably complaint because campus, as committee of LPTK, is often not in accordance with innovation in reality which emphasizes a practical thing. So far, there is a gap between theory and content which is taught in campus and practical thing in Schools. As a result, training process in campus is not only less relevant, but also less interesting, less challenging, and less supportive to the improving teaching's quality". For that reason, we need to reform the process of prospective teacher preparation in LPTK PTKIN. In the future, graduates of LPTK PTKIN are expected to be more ready professional teacher in improving teaching quality in schools" (Kamaruddin Amin, 2017).

The idea of improvement and reformation of LPTK which is proposed by Directorate General of Islamic Education should be a strategic discourse to fix and empower the institution of LPTK. This idea is in accordance with Setiana's opinion (2015) that so far LPTK is only placed as the institution of licensing for teacher profession. By seeing the spirit of the Act for teacher which becomes the reference today, consecutive model will be a new direction of teacher training modal in Indonesia. LPTK function will only be functioned 
as expanded certification institution (wider mandate) with basis of LPTKness. Concurrent model is pointed as reference by giving more enforcement in mastering subjects (subject matter). In conclusion, universities which has role as LPTK must be more strengthened and encouraged to be better. The government must pay high attention to the execution of teacher training in LPTK. There will be a tendency of the reduction of LPTK's existence and function as only institution for teacher profession certification.

The need of developing and enforcing LPTK is also explained by the Vice Dean of Academic and Institution Division of the Faculty of Tarbiyah and Teacher Training (FTK) UIN Ar-Raniry Banda Aceh that it is required to improve and reform management of institution, academic service, facilities for training in LPTK entirely. The current condition of LPTK is far from expectation and standard as professional institution which is prepared for producing the next teacher. This indication can be seen especially at the inadequate teachinglearning-supporting facilities. For example, micro teaching laboratory is out of standard, science and language laboratory are not adequate, and the collection of standardized reference book in library is not complete yet (data was supported by the interview with the Vice Dean of FTK UIN Ar-Raniry, April 2018).

\section{THE IMPLEMENTATION OF ACT NO 14 OF YEAR 2005 AND TRANSFORMATION OF RELIGIOUS EDUCATION}

Good implementation of Act No. 14 of the year 2005 will significantly affect the improvement of educational qualification and quality, and particularly professionality of religious education teachers. These skilled and well-qualified religious education teachers will influence the quality of religious education for the Acehnese people. Finally, religion will give great influence to character shaping, worldview and culture among society. There are two dimensions of diversity which is related to people's life, i.e. (1) Religion for its believers is used as a worldview which explains the existence of human in the world, explain the direction and aim of human's life, (2) Religion does not only regulate the relationship between human and God, but also regulates relationship among human and relationship between human and other creatures (Nurcholis Madjid, 2001: 117). Religion is a faith which can be part and core of value systems which exist in people's culture and become motor and controller of human's behavior to become in accordance with cultural values and religious' teaching.

There are two big assets which support the implementation of values of religions in Indonesia. Both assets include the cultural assets (i.e. custom and 
culture which is full of religious values) and structural assets by relying on Pancasila and UUD 1945 which juridically and constitutionally contain noble values which were born from universal Islamic values and religion values. Therefore, it is hoped that the two assets can be synergized and run well so that there will be a good governmental system. Furthermore, the presence of religious education teachers as part of civil servant who is diretcly involved in the process of internalization and implementation of religious values in daily life is very crucial. Internalization of religious values is given by teachers to learners. There will be further implication in term of bureaucracy system when they become part of civil servant, so that there will be a good and clean governance system.

A good government coordinates, controls, and balances between government and people. The government can put up the values of people's will that can improve people's ability to gain the independence, to conduct development and put up justice among people. Good and clean government is the reflection of manner in which ruling is conducted by people who are ruled by government related to social, cultural, political, educational, law and economical sources. Clean government can be seen from the appearance of the effective, efficient, honest, equal, transparent, and responsible government's activities. The clean government does not also commit a corruption, collusion, nepotism, and abusive power. Government officers apply justice, law supremacy, willingness, honestly, trusteeship, and human right as well as perform religious teachings (Deliar Noer, 2003).

The illustration of good and clean government above can be a model and ambitions which must be realized by the Indonesian government. To achieve these Nobel aims, the government must create a system, a police and a program which can improve and develop a good order in government. Government system must show a modern governance system which put up the values of humanity and democracy, as well as souled by the values of religion and values of culture. The governance order that is souled and decorated by those various values will form a dynamic, democratic, egalitarian, transparent, and strong governance system. Meanwhile, the government's policy which is formulated and conducted must be in accordance with the paradigm and system of the good and clean government. On the other hand, substantially, every policy of government must provide a big room for the implementation of religious values in system and order of the government.

Indonesia, as described in the earlier condition, needs real and systematic efforts by all people in every aspect of life, one of which is education. In this term, it is needed to make a transformation of Islamic education in the 
development structure of Indonesia. Transformation of Islamic education can be implemented in three forms. First, religious education must be a core component national education curriculum. Religious education which is oriented to the improvement of quality of faith to Allah needs to be created as national education, especially in anticipating moral and behavioral crises, including improving education quality. One of the mistakes of national education policy which directly or indirectly affect educational performance is that religious education (especially Islamic education) does not become the substance of national curriculum and Islamic education institution is less noticed in national education system. It is time for the government to create a regulation and policy of national education in which religious teachings become main content in national curriculum to strengthen faith, fear, and moral among people (Sulaiman Ibrahin, 2014).

Second, religious education in schools and universities must be taught by teachers and lecturers who are well-qualified and professional. The government and related stakeholders must evaluate and regulate the existence of teachers and lecturers who teach religious education to students throughout Indonesia. It is conducted in order to ensure that teachers and lecturers who are appointed to teach future generation really have ability and good knowledge about religion, are pious individuals and have moral and good conduct. On the other hand, teachers and lecturers who have lack of understanding religious knowledge, not pious and have no good attitude cannot be a good example in daily life. Third, the Implementation of religious education material must be adjusted to the needs and the age of learners. To avoid the emerging of radicalism among students, there should be a concrete way in the process of learning; i.e. adjusting religious education materials to the needs and the age of learners. Those who are beginner and intermediate students should be taught religious teachings that are related to belief, worship, attitude, and teaching about social interaction. It should be avoided to teach them the materials about politics. After they understand main materials and perform them very well, it is allowed for them to be taught topic about politics and state administration since they are mentally ready and they have good knowledge. The logic consequence can prevent the next generation of this nation from radicalism which has been troubling the nation today.

\section{CONCLUSION}

The implementation of Act No. 14, 2005 and the government's regulation No. 74, 2008 about teacher is a form of intervention and hegemony of this country toward educational field. The born of those regulations is as an answer of 
the problem of the low qualification and quality of teachers in Indonesia in general and Aceh in particular. This article, which is based on the analysis of literatures about qualification, competency and certification of teacher, shows that the existence of the Act and government regulation which regulate teacher's competency still needs deep evaluation because the first purpose of implementing of those regulation is not well achieved yet. This review provides the illustration that in one side of the formulation of the Act and government regulation together with social cultural context of the Acehnese, there is a difference which should be adjusted and completed, so that the purpose of the implementation of the Act and government regulations can be realized in the frame of people's benefits.

On the other side, the implementation of Act No. 14, 2008 does not fully affect the improvement of teacher's competency maximally. It is not ignored that there is improvement of qualification and competency of religious education teachers in Aceh after the implementation of the Act No. 14 year 2005. However, it can be found that correlation between the increasing number of teachers is not in line with the improving religious education teachers' competences in Aceh. The research shows that there is tight relationship between the obstacles of teacher's competency achievement and the existence of LPTK as an institution for training and empowering teachers' quality, which cannot get serious attention in the frame of regulation. Formulation of the Act No. 14 year 2005 does not enough discuss about LPTK, so that developing and improving LPTK does not become an attention and main program of the government. This work shows that a complete study is needed which is more based on substance of content of Act No. 14, 2005 related to improving qualification and competency of teacher which cannot be separated with improving the quality of LPTK as an institution which has duty and strategic function to improve quality and professionality of teachers in Indonesia.

\section{BIBLIOGRAPHY}

Abid, A. M. (2001). Agama, Negara dan Penerapan Syariah. Translated by Mujiburrahman, Yogyarakat, Fajar Pustaka Baru.

Al-Attas, S. M. N. (1980). The Concept of Islamic Education. X, 16. https://doi. org/10.1007 /s13398-014-0173-7.2

Asmin, S. A. (2017). The Influence Of Pedagogic, Professional Competency, And Work Motivation On Teacher Performance Of Elementary School. Jurnal Pendidikan, Volume 18, Nomor 2, September 2017, p. $1-12$ 
Atkinson, J. (2017). Qualitative Methods Book Title: Journey into Social Activism Book Subtitle: Qualitative Approaches This Chapter Explores. Journey into Social Activism: 27-64. https://www-jstor org.ezproxy. napier.ac.uk/stable/pdf/j.ctt1hfr0rk.5.pdf? $\quad$ refreqid=excelsior\%3A5c610e25e7f3d31e1e6b9145da896748.

Barney, H. (2004). Accountability in the Legal Profession. in Organizational Improvement and Accountability. p. 65-84.

Barr, A. S. (1960). The Assessment of the Teacher's Personality. The School Review. Vol. 68. No. 4. p. 400-408.

Buto, Z. A. (2016). Pengembangan Kompetensi Profesionalisme Guru PAI. Jurnal MIQOT Vol. XL No. 2 Juli-Desember 2016, p. 370-388.

Cohen, D. K., Susan, L. M. and Goldin, S. (2007). Policy and Practice: The Dilemma. American Journal of Education. Vol. 113. No. 4. p. 515-548.

Thomas, C. J. (1994 ). Research and Teacher Education: In Search of Common Ground. Journal for Research in Mathematics Education. Vol. 25. No. 6. p. 608-636.

Noer, D. (2003). Islam dan Politik. Jakarta: Yayasan Risalah.

Destiana, D., Kurnia, D., \& Sumardi. (2012). Hubungan Antara Kompetensi Pedagogik dengan Kinerja Guru Sekolah Dasar. Jurnal FKIP Universitas Pakuan. WorldWideWeb:http://ejournal.unpak.ac.id/download. php?file $=$ mahasiswa\&id $=559 \&$ name $=e-J u r n a l \% 20$ (Dita\%20Destiana, \%20037108082).pdf.

Dreher, A. and Kuntze, S. (2015). Teachers' professional knowledge and noticing: The case of multiple representations in the mathematics classroom. in Educational Studies in Mathematics. Vol. 88. No. 1. p. 89-114. DOI: $10.1007 /$ s10649-014-9577-8

Feralys, N. M. (2015). Kompetensi Guru Dalam Peningkatan Prestasi Belajar Pada Smp Negeri Dalam Kota Banda Aceh. Jurnal Jurnal Administrasi Pendidikan Pascasarja Universitas Syiah Kuala, Volume 3, No. 1.

Gehlbach, H. (2010). The Social Side of School: Why Teachers Need Social Psychology. in Educational Psychology Review. Vol. 22. No. 3. p. 349362.

Goto, Y., Affan, M., Agussabti, Nurdin, Y., Yuliana, D. K., \& Ardiansyah. (2012). Tsunami evacuation simulation for disaster education and city planning. Journal of Disaster Research.

Amin, K. (2017). Reformasi LPTK di Lingkungan PTKIN. Unpublished paper. 
Kementerian Agama RI.

Klingstedt, J. L., Jorge, D. and Schroeder-Donofrio, A. (1981). The Education

Profession: Conceputal and Instructional Models. in Peabody Journal of Education. Vol. 59. No. 1.p. 15-23.

Liakopoulou, M. ( 2011). Teachers' Pedagogical Copetence as a Prerequisite for Entering the Profession. in European Journal of Education. Vol. 46. No. 4. p- 474-488.

Ludington, J. R. (1940). Teacher Education. in The Phi Delta Kappan. Vol. 22. No. 5. p.257-259, 263.

Ma, N., Shuang, X. and Yuan, D. J. (2018). A Peer Coaching-based Professional Development Approach to Improving the Learning Participation and Learning Design Skills of In-Service Teachers. in Journal of Educational Technology \& Sociey. Vol. 21. No. 2. p. 291-304. ISSN: 1436-4522.

Mintrop, H. (1999). Changing Core Beliefs and Practices Through Systemic Reform: The Case of Germany after the Fall of Socialism. in Educational Evaluaion and Policy Analysis. Vol. 21. No. 3. p. 271-296

Mulyanto, A. S. (2008). Hubungan Antara Kompetensi Profesional Guru dan Konsep Diri Guru dengan Kinerja Guru Kelas V Sekolah Dasar Negeri di Kecamatan Grogol Kabupaten Sukoharjo Tahun 2008/2009. Unpublished Thesis, Universitas Sebelas Maret Surakarta. World Wide Web: http://eprints.uns.ac.id/8141/1/ 74241007200 902531.pdf.

Nasir, U. ( 2007). Manajemen Peningkatan Kinerja Guru. Bandung: Mutiara Ilmu.

Madjid, N. (2001). Masyarakat Religius; Membumikan Nilai-Nilai Islam dalam Kehidupan Masyarakat. Jakarta: Paramadinah.

Oktari, R. S., Shiwaku, K., Munadi, K., Syamsidik, \& Shaw, R. (2015). A conceptual model of a school-community collaborative network in enhancing coastal community resilience in Banda Aceh, Indonesia. in International Journal of Disaster Risk Reduction. https://doi.org/10.1016/j. ijdrr.2015.02.006

Pantic, N. et al. (2011). Teacher Competence as a Basis for Teacher Education: Comparing Views of Teachers and Teacher Educators in Five Western Balkan Country. in Comparative Education Review. Vol. 55. No. 2. p. 165-188.

Peraturan Pemerintah Nomor 74 tahun 2008 tentang Guru

Rebell, M. A. and Molly, A. H. (2004). Highly Qualified' Teachers: Pretense or 
Legal Requirement. in The Phi Delta Kappan. Vol. 85. No. 9. p. 690-696

Rosemary, R., Si, M., \& Mahdi, S. (2013). “Tantangan Implementasi Sistem Pendidikan Berbasis Nilai Islami ( SPBNI )”, 7, pp. 16-34.

Sekretariat Daerah Pemerintah Aceh (2014). Qanun Aceh No. 11 Tahun 2014 Tentang Penyelenggaraan Pendidikan.

Setiana, D. S. (2015). Pengembangan LPTK sebagai tugas matakuliah Kajian Ilmu Matematika. Jogyakarta: UMY.

Shah, R., \& Lopes, C. M. (2014). Education and social change in post-conflict and post-disaster Aceh, Indonesia. In International Journal of Educational Development. https://doi.org/10.1016/j.ijedudev.2014.06.005

Ibrahim, S. M. (2014). Pendikan Islam di Indonesia. in Jurnal Irfani, Volume. 10 Nomor 1, Juni 2014, p. 108.

Suraiya, C. (2015). Implementation of Islamic Education in Banda Aceh City: Study of Qanun No. 5 of 2008 Implementation. In Jurnal Ilmiah Didaktika, 16(1), p. 1-22.

Symonds, P. (1947). Personality of the Teacher. In The Journal of Educational Research. Vol. 40. No. 9. p. 652-661.

The Harvard Law Review Association (2015). Education Policy Litigation as Devolution. Harvard Law Review. Vol. 128. No. 3. p. 929-950.

Tichá, M. and Hošpesová, A. (2013). Developing teachers'subject didactic competence through problem posing. Educational Studies in Mathematics. Vol. 83. No. 1. p. 133-143

Undang-Undang Nomor 11 tahun 2006 Tentang Pemerintah Aceh

Undang-Undang Nomor 14 tahun 2005 tentang Guru dan Dosen

Yusoff, N. bt. (2014). Integrasi Nilai Islami dan Budaya Aceh Berdasarkan Kurikulum Karakter. Humanus, XIII(1). 